\title{
AN ANALYSIS OF EFFICIENCY OF GENERAL INSURANCE INDUSTRY IN INDIA
}

\author{
ABHIJIT SINHA \\ Vidyasagar University, \\ Midnapore,India \\ KALPATARU BANDOPADHYAY \\ Vidyasagar University, \\ Midnapore, India
}

\begin{abstract}
It is well known that the overall insurance sector in India has been undergoing a series of reforms from time to time. The drastic change that re-designed the contours of the industry is the implementation of the Malhotra Committee Recommendations which opened up the landscape to the private nonlife insurers in 2000. The present study has been taken up to determine the efficiency of the non-life sector and the insurers using Data Envelopment Analysis (DEA). The empirical research also aims to statistically test whether there is any year-wise significant difference between the two sectors in respect of the overall efficiency. For the purpose, appropriate statistical test is applied. The study is based on secondary data collected from the Insurance Regulatory Authority of India (IRDA) Annual Reports. The sample size for this study is twelve including all the four insurers from the public sector and the remaining from the private sector. The results of the analysis showed that in terms of technical and pure technical efficiency, the overall result of the public sector surpasses that of the private. However, the findings of the Mann-Whitney U Test revealed that the result with respect to the statistical difference is mixed.
\end{abstract}

Keywords: Non-life; India; data envelopment analysis; mann-whitney U Test.

\section{Introduction}

The recommendation of the Malhotra Committee was instrumental in bringing reforms in the insurance sector, both the life and non-life sector. The life insurance sector is concerned with the business of insuring human lives, in contrast to the non-life insurance (also sometimes referred to as the general insurance) business which is concerned with insuring oneself against occurrences of other than that which is leading to death or disability etc. Hence, in simple words, we mean that non-life insurance is concerned with insuring oneself against loss to vehicles, property, cargo or protecting oneself against the loss caused due to damage on seas, due to fire, burglary, during travel etc. The most important issue in this regard was to open up the economy for the private insurers. More than a decade has passed since the inception of private insurance business in India. The nature of the insurance companies is such that it cannot earn profit in its initial years and takes a long time to become profitable. It is time to assess the performance of the private insurers in order to get an idea about their focus on short-term or long-term. Theoretically, there cannot be any excellent or poor performance in absolute 
terms. The performance of any business concern in general depends on the economic condition of the country and also on the condition of the industry in which it belongs. During economic boom, almost all businesses would make decent profit. But during recession, even the efficient firms may struggle to earn profit. During the global financial meltdown in the year 2008, the players of financial sector were severely beaten down and adversely affected in general. However, being a conservative and highly controlled economy, India was least affected. In this context, this paper seeks to examine the efficiency of general insurance industry before and after 2008. The paper further wishes to compare the efficiency of private insurers and public sector insurers before and after the global financial crisis.

\section{Literature Review}

There are several literatures on assessment of non-life insurer in the Indian context and abroad. For better understanding of the studies already made, this part has been divided into Asian and Non-Asian studies. The former has been further divided into Indian and non-Indian studies.

\section{Indian studies}

In respect of the tudies focusing on Asian countries, a few studies have been conducted in the Indian context. Bawa and Ruchita (2011) studied the health insurers of the country for the period 2002-03 to 2009-10 which revealed the dominance of the public sector players with New India Assurance Company Limited and National Insurance Company Limited being the best. However, at the same time, they pointed towards a declining trend during the period which was in contradiction to the trend observed for the private insurers. Chakraborty, Dutta and Sengupta (2012) investigated the non-life insurance sector using Battese and Collie (1995) Stochastic Frontier inefficiency-effect model and Fixed Effect Stochastic Frontier model to observe that two-third of the sample showed gains in productivity. Moreover, net claims, operating expenses and investments were found to be positively related to the net premiums. A study by Rao and Venkateshwarlu (2014) analysed the private non-life insurance sector in India using the Stochastic Frontier analysis which revealed that though there was an overall progress with Bharti AXA as the most efficient insurer, the average industry efficiency was very low at around $35 \%$. None of these studies have compared the efficiency of private and public sector insurers before and after the financial crisis.

\section{Non-Indian Asian studies}

There are a number of studies that have focused on the insurance industry of East and South East Asia (Abidin \& Cabanda, 2011, Eckles \& Saardchom, 2007; Hsiao 2006; Huang, 2007; Hwang \& Kao 2006, Lee \& Kim 2008). An intercountry study on South-East Asian countries revealed that the productivity growth of Korea and Phillipines was better than Taiwan and Thailand with an overall increasing trend that was visible for the insurers. (Boonyasai, Grace \& Skipper, 2002). Hsiao (2006) looked into the performance measurement of investment for 25 life insurers of Taiwan during the period 19982002 and intended to compare the performances of foreign insurers with domestic insurers. The research provided evidence to show that the total factor productivity growth was found to be close to $11 \%$ by the researchers. The overall study found no significant difference in the rank of overall efficiency and pure technical efficiency between foreign and domestic players, except in a few years. Hwang and Kao (2006) utilized the two-stage Data Envelopment Analysis (DEA) technique to study twenty four Taiwanese non-life insurance companies. The first stage measured the marketability aspect whereas the second stage looked into the profitability aspect. An interesting finding was that the companies that had efficiency in the traditional stage one could never achieve efficiency in both the stages. Also, there was no significant difference between the domestic and foreign insurers as well as those with different sizes. Qiu and Chen (2006) study found the mean efficiency 
in the Chinese insurance industry to follow a continuous declining trend ranging from 0.49 to 0.64 . The comparison of the results of the Chinese with those of the international insurers revealed that the latter showed very poor performance in terms of technical efficiency. The reason behind inefficiency is related to both managerial and scale, but for the international insurers pure technical efficiency did not play a severe down-pulling effect. Eckles and Saardchom (2007) analysed the technical and scale efficiency in the Thai Non-Life insurance industry for the period 1997-2003 which showed that the technical efficiency ranged from 0.691 to 0.791 . With regard to returns to scale, the study pointed to majority of the firms operating under CRS (constant returns to scale), followed by DRS (decreasing returns to scale) and the remaining under IRS (increasing returns to scale). A similar work has been covered by Lin (2002) and Hsiao, Pai, Shi and Su (2011). Huang (2007) predicted that the cost efficiency of the private and foreign Chinese insurers was better than the state-owned and domestic companies which was in contradiction to the findings of the profit efficiency results. A study on Pakistan revealed an increasing trend of efficiency (Afza and Jam-e-Kausar, 2010). An investigation on efficiency of Iranian life insurers showed that the performance of the public sector companies was significantly much better than the private counterparts (Saeidy and Kazemipour, 2011). Abidin and Cabanda (2011) studied the efficiency of Indonesian non-life insurers for the period 2005-07 where they also applied the tobit (censored) regression model to understand the impact of different variables on the firm's efficiency.

\section{Non-Asian studies}

It is definite from the quantum of research in the foreign countries, particularly the US, Europe and African countries that insurance sector has been very closely explored by researchers from different aspects. Cummins, Tennyson and Weiss (1999) looked into the efficiency aspect of US. life insurers as a result of mergers and acquisitions for the period 1988-1995 using DEA. A study of the Portuguese insurers using productivity growth showed the mean to be $11 \%$ with three-fourth of the insurers showing a positive result. Delhausse, Fetcher, Perelman and Pestieau (1995) made an intercountry analysis on two European countries by comparing Belgium and France in terms of technical and scale efficiency using DEA and stochastic frontier methods (parametric maximum likelihood procedure). The empirical study showed that though the average efficiency was low in both the countries, France was better placed than Belgium in terms of efficiency and non-profit companies were better placed compared to the profit-making companies. The multiple regression models revealed that efficiency was influenced positively by size, claims ratio and reinsurance ratio (except in the case of France) and negatively related with higher specialization in car insurance. A few other inter-country studies on the insurance industry include Eling and Luhnen (2009) and Diacon, Starkey and O' Brien (2002). Diacon, Starkey and O' Brien (2002) make an intercountry efficiency study on insurers across 15 European countries for the period 1996-99.

Ibiwoye (2010) developed a conceptual paper and identified the reason behind increasing popularity of the frontier methods in performance assessment of decision-making units (DMUs). The researcher used data of ten Nigerian insurance companies to show how efficiency analysis could be done by making computations of technical and scale efficiency scores. Results showed that high level of technical efficiency existed under both constant returns to scale and variable returns to scale but in both the cases there existed scale inefficiency, thereby concluding that size made a difference and lead to decreasing returns to scale. Owusu-Ansah, Dontwi, Seidu, Abudulai and Sebil (2010) analysed the efficiency levels of Ghanaian general insurers which revealed that the insurers operated at an average overall efficiency of $68 \%$, technical efficiency of $87 \%$ and scale efficiency of $78 \%$. The Mann-Whitney U-test showed that larger insurance companies and those with higher market share attained greater efficiency levels. 


\section{Research Gap}

The insurance sector including the general insurance sector in India is special as regards the co-existence of both public sector undertakings and private sector players. There have been attempts made in the past which focused only on the efficiency of the sector and the insurers, in particular. There are not enough studies to gauge the relative performance of Indian general insurance business and to compare the efficiency of private insurers and public insurers. Further, looking into the financial turmoil that started in 2008, it is extremely important to look into the status of the insurers in terms of their performance. Only a handful of studies have been made in the Indian context, taking postrecession also in the study period. But, none of the studies aimed to compare the level of impact or know whether there has been any difference in the level of impact due to the economic slowdown. This empirical research aims to plug in this gap and is a serious attempt to capture whether there is any significant difference in the effect of financial crisis on the insurance sector in general and in the private and public sector in particular.

\section{Research Methodology}

Data source: For the purpose of this study, secondary data has been collected from various issues of the Insurance Regulatory Development Authority (IRDA) Annual Reports. This empirical research covers a period from 2004-05 to 2011-12.

Sampling technique used: In this study, Purposive Sampling Method is used to select the samples. Twelve insurers have been chosen comprising of four from the public sector and remaining from the private counterpart. The necessity of existence in the business during all years of the study period was the criterion for sample selection.

\section{Research Method followed:-}

It has been opined by experts that financial ratio analysis is an inferior method compared to the frontier methodologies (Eling \& Luhnen, 2010). Accordingly, for this empirical research, a twoinput, two-output output-oriented DEA is used to arrive at the relative efficiency scores viz., technical efficiency, pure technical and scale. In fact, this technique is applied in support of the argument given by Coelli (2004) that the non-parametric approach is simple and easy to calculate since it does not require the specification of the functional for.

The term efficiency had been introduced to the industrial research studies by Koopman and Farrell in the 1950s. The term efficiency can be looked at from two different angles, one from the output side and the other from the input side. Hence, depending upon the approach taken, the measure of technical efficiency will be different. For an output-oriented case, technical efficiency can be measured as the actual output produced as a ratio of the maximum output that can be produced, given the fixed inputs. Hence, the higher is the ratio, the higher is the efficiency. If the actual output is the same as the maximum output that is possible in that situation, the efficiency is one. On the other hand, for an input-oriented case, the measure of technical efficiency is the ratio between the minimum input to be used and the actual input used, given the fixed output. Hence, the lower is the actual input, the higher is the efficiency and vice-versa.

For the purpose of our study, the output-oriented model has been used since, in this era of deregulated and competitive markets, businesses focus on higher revenues, keeping the cost under control through different cost management techniques. In efficiency studies, in order to help managers in better decision-making, the term 'technical efficiency' has been further broken into two multiplicative factors, viz. pure technical efficiency and scale efficiency. The first factor is considered to be arising due to managerial inefficiency and poor judgement, whereas the latter arises due to inefficiency from operating at a non-optimal point (either suboptimal or supra-optimal level) of the production curve. 


\section{Choice of variables}

It is well known from the literatures on banking and insurance studies that there are two common approaches in choosing input and output variables, viz. the intermediation approach and the flow approach. The variables considered for the study are as per the second approach. The inputs are operating expenses and commission, whereas, the outputs are net premium and investment income. The idea behind choosing the above mentioned variables is that in order to stand out and withstand tough competitive situations, it is prudent for businesses to adopt the flow approach which focuses on converting from expenses to incomes. In other words, it is extremely vital for insurers, especially the nonlife insurers to judiciously expend their money so that it helps to generate maximum income in the form of premium and investment returns. It is becoming even more vital in India due to the high rate of underwriting commission and claims that are required to be borne by the non-life insurers. Moreover, the availability of data in the reports was also kept in mind before finalizing the variables. A list of variables used in earlier studies is given in the table below. The table below (No. 1) cites the different variables used by different researchers for efficiency analysis of the insurance industry.

Table 1

Input and Output Variables used in various Efficiency Studies on Insurance

\begin{tabular}{|c|c|c|c|}
\hline \multirow[t]{2}{*}{ Author(s) and year } & \multicolumn{2}{|c|}{ Variables } & \multirow[t]{2}{*}{ Area of work } \\
\hline & Input(s) & Output(s) & \\
\hline $\begin{array}{l}\text { Abidin and Cabanda } \\
\text { (2011) }\end{array}$ & $\begin{array}{l}\text { Business and } \\
\text { administration expenses, } \\
\text { marketing expense }\end{array}$ & $\begin{array}{l}\text { Premium income, net } \\
\text { underwriting income and } \\
\text { investment income }\end{array}$ & Non-Life \\
\hline $\begin{array}{l}\text { Bawa and Ruchita } \\
\text { (2011) }\end{array}$ & $\begin{array}{l}\text { Equity capital, labour } \\
\text { expenses (includes } \\
\text { commission, agents' } \\
\text { fee, referral and other } \\
\text { expenditure) }\end{array}$ & Net premium & Health \\
\hline $\begin{array}{l}\text { Boonyasai et. al } \\
(2002)\end{array}$ & Labour, capital, materials & $\begin{array}{l}\text { Premium income, net } \\
\text { investment income }\end{array}$ & Life \\
\hline $\begin{array}{l}\text { Chaffai and Quertani } \\
\text { (2002) }\end{array}$ & $\begin{array}{l}\text { Labour, physical capital } \\
\text { and financial capital }\end{array}$ & Total premiums earned & Life, Non-life \\
\hline $\begin{array}{l}\text { Davutyan and } \\
\text { Klumpes (2008) }\end{array}$ & $\begin{array}{l}\text { Labour, business services, } \\
\text { equity capital }\end{array}$ & $\begin{array}{l}\text { Present value of losses } \\
\text { invested, premiums, } \\
\text { invested assets }\end{array}$ & Life, Non-life \\
\hline
\end{tabular}

(Continued) 


\begin{tabular}{|c|c|c|c|}
\hline \multirow[t]{2}{*}{ Author(s) and year } & \multicolumn{2}{|c|}{ Variables } & \multirow[t]{2}{*}{ Area of work } \\
\hline & Input(s) & Output(s) & \\
\hline Deacon (2001) & $\begin{array}{l}\text { Total operating expense, } \\
\text { total capital, total } \\
\text { technical reserves, total } \\
\text { borrowings from creditors }\end{array}$ & $\begin{array}{l}\text { Net premium, total } \\
\text { investment income }\end{array}$ & General insurance \\
\hline $\begin{array}{l}\text { Diacon, Starkey and } \\
\text { O'Brien (2002) }\end{array}$ & $\begin{array}{l}\text { Total operating expenses, } \\
\text { commissions, capital, } \\
\text { technical reserves, total } \\
\text { borrowings }\end{array}$ & $\begin{array}{l}\text { Net premium, total } \\
\text { investment income }\end{array}$ & Non-life \\
\hline $\begin{array}{l}\text { Ennsfellner et al. } \\
\text { (2004) }\end{array}$ & $\begin{array}{l}\text { Net operating expenses, } \\
\text { equity capital and } \\
\text { technical provisions }\end{array}$ & $\begin{array}{l}\text { Incurred benefits, changes } \\
\text { in reserves, total invested } \\
\text { assets }\end{array}$ & Health / Life \\
\hline $\begin{array}{l}\text { Jenlin and Wen } \\
\text { (2008) }\end{array}$ & $\begin{array}{l}\text { Investment expenses and } \\
\text { Underwriting expenses }\end{array}$ & $\begin{array}{l}\text { Net investment income to } \\
\text { total assets, Loss incurred } \\
\text { to net premium }\end{array}$ & Non-Life \\
\hline Klumpes (2007) & $\begin{array}{l}\text { Labour, business services, } \\
\text { debt capital, equity capital }\end{array}$ & $\begin{array}{l}\text { Premiums, investment } \\
\text { income }\end{array}$ & Life, non-life \\
\hline Latif (2011) & $\begin{array}{l}\text { Labour, operating } \\
\text { expenses }\end{array}$ & Investment earnings & Non-Life Insurance \\
\hline $\begin{array}{l}\text { Mansor and Radom } \\
\text { (2000) }\end{array}$ & $\begin{array}{l}\text { Claims, commission, } \\
\text { salaries, expenses, other } \\
\text { costs }\end{array}$ & $\begin{array}{l}\text { New policy sales, } \\
\text { premium, policies in force }\end{array}$ & Life \\
\hline Rai (1996) & Labour, Capital, Claims & Premium & Insurance firms \\
\hline Wende et. al (2008) & $\begin{array}{l}\text { Operating expenses, } \\
\text { equity capital, debt capital }\end{array}$ & $\begin{array}{l}\text { Claims incurred, total } \\
\text { invested assets }\end{array}$ & Property-liability \\
\hline Yao et. al (2007) & $\begin{array}{l}\text { Labour, capital, payment } \\
\text { and benefits }\end{array}$ & $\begin{array}{l}\text { Premium, investment } \\
\text { income }\end{array}$ & Life, Non-life \\
\hline
\end{tabular}

Source: Adopted from Sinha (2013) 
This test is followed by the Mann-Whitney $\mathrm{U}$ Test to test the difference between the two sectors.

\section{Analysis and Findings}

\section{Overall Industry Results}

The results of the efficiency analysis are discussed in the paragraphs below. Chart 1 below assesses the overall sector wise efficiency insurance firms. In other words, it shows to what extent the insurers have produced their outputs in relation to their best set competitors in the reference set. Since, the output-oriented model is used, it helps to understand the scope of increasing the output, keeping the input level the same.

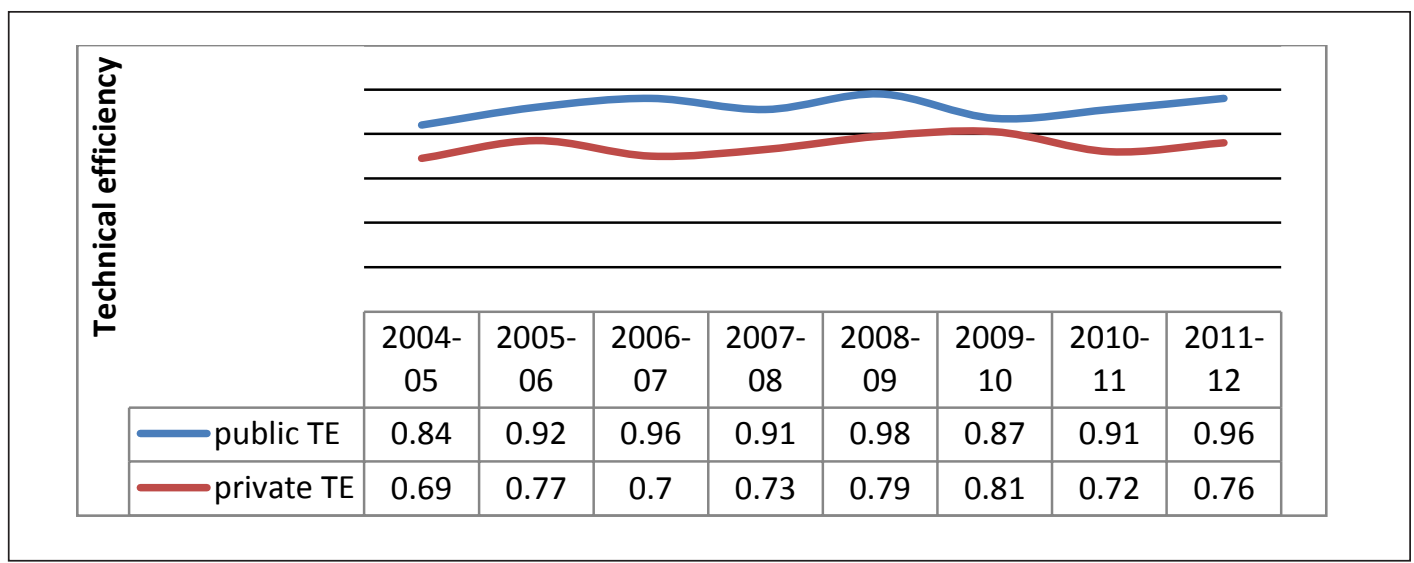

Source: Computed by the authors

Chart 1: Average technical efficiency results of the sectors

From the above, it is evident that overall situation in the industry is very positive since there is an overall uptrend during the study period. From the scores of the public and the private sector, it is clear that there is immense scope for improvement by the private sector. In 2004-05, the sector produced only $69 \%$ in comparison to its potential an in comparison to $84 \%$ produced by the public sector. Moreover, looking at the line graph, it is clear that the gap was coming down in a few years, which however changed during the last two years.

Chart 2 below, highlights the position of the sector in terms of its managerial efficiency. In other words, the scores point to the level of managerial prudence and capability which has contributed to the efficiency score. 


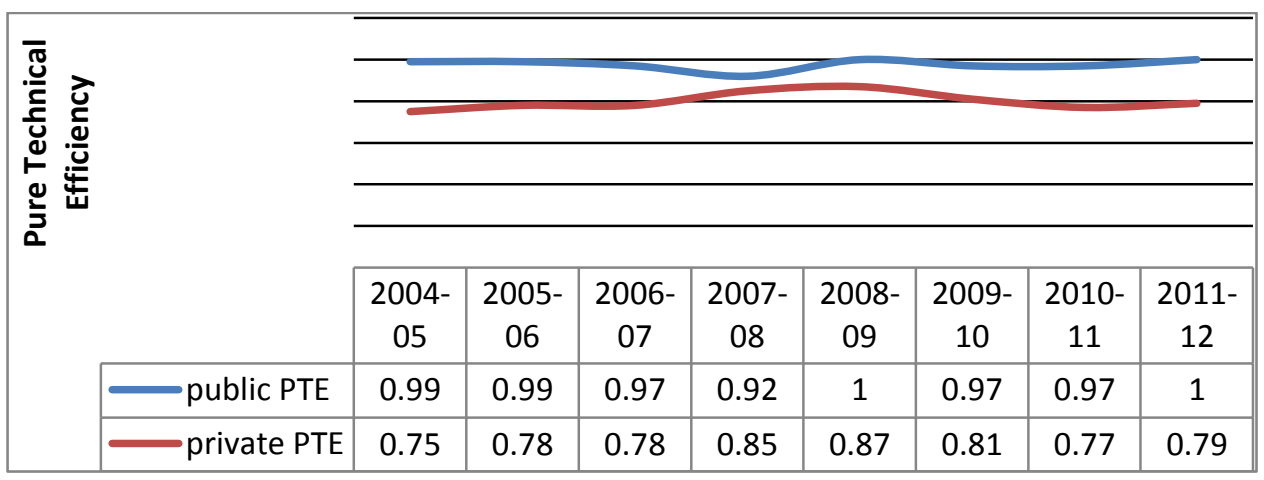

Source. Computed by the authors

Chart 2. Average pure technical efficiency

\section{Results of the Sectors}

From the chart above, it is evident that overall the trend is positive for the public sector since it reflects stagnancy in the scores of almost $100 \%$. In contrast, the private sector which showed $75 \%$ efficiency in 2004-05 stands very close to that score with $79 \%$ efficiency. Hence, the private sector should rethink its strategies that will help to improve its relative score. Moreover, it can be observed from the graph that during the middle years, the gap had reduced a lot, but after the de-tariffing took place in the middle of the last decade, there seems to be a widening gap between the two sectoral scores.

The chart below (No. 3) gives a picture about the sectoral status in terms of its scale efficiency results which gives an idea about the extent of usage of the size of the operations. A score of "not equal to one" implies that the unit is producing at the non-minimal level; a score of one points to the production at the most productive scale size.

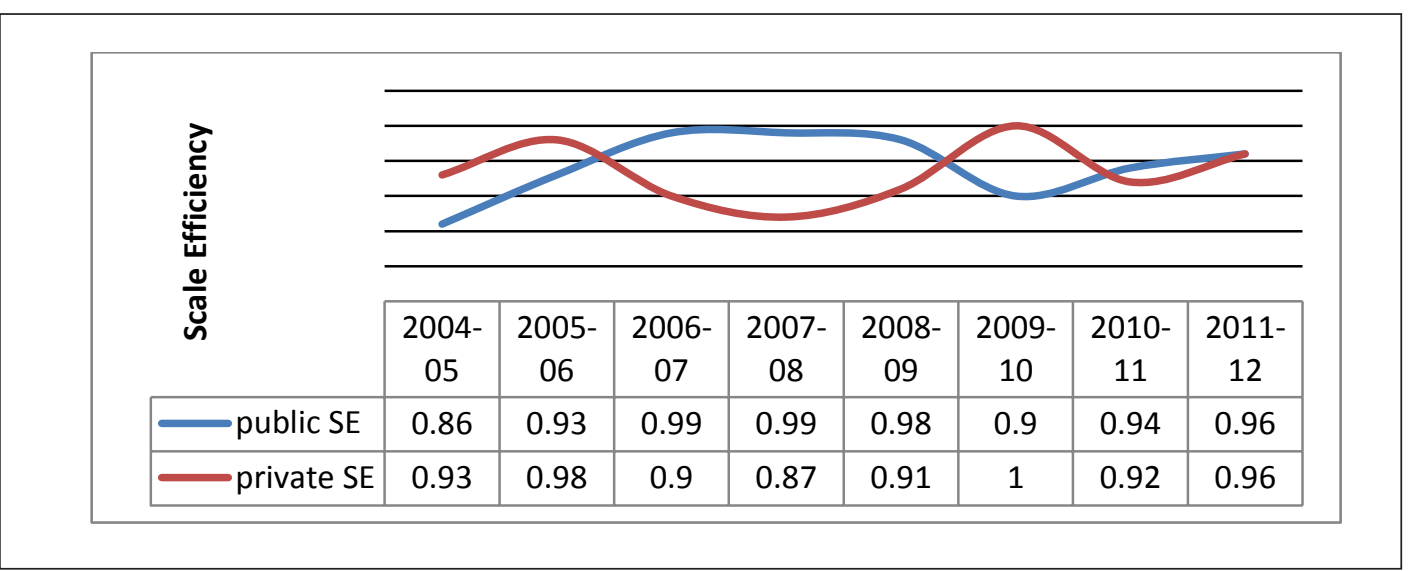

Source: Computed by the authors

Chart 3: Average scale efficiency results of the sectors 
In this aspect, both the sectors are found to perform well. In particular, the public sector showed immense improvement with an increase from $86 \%$ in $2004-05$ to $96 \%$ in $2011-12$. The private sector, on the other hand, has maintained consistency with all the scores remaining in a low range of $93 \%$ and $100 \%$. Public sector which was dominated by the private sector in the beginning and later on outperformed its rival and the trend continues even today.

\section{Individual Insurers’ Results}

In order to get a better picture of the individual performance, an analysis has been done in order to find their positions in the quartile scale for different years. The insurers on the basis of their technical efficiency results have been placed in different categories, viz. first quartile $\left(Q_{1)}\right.$ between first two quartiles $\left(\mathrm{Q}_{1} \mathrm{Q}_{2}\right)$ between next two quartiles $\left(\mathrm{Q}_{2} \mathrm{Q}_{3}\right)$ and beyond third quartile $\left(>Q_{3}\right)$.

Table 2

Position of Insurers on the Quartile Scale Using Technical Efficiency Scores

\begin{tabular}{|c|c|c|c|c|}
\hline Year & $<Q_{1}$ & $\mathrm{Q}_{1} \mathrm{Q}_{2}$ & $\mathrm{Q}_{2} \mathrm{Q}_{3}$ & $>Q_{3}$ \\
\hline & HDFC, Tata AIG & Cholamandalam, & Bajaj Allianz, & ICICI Lombard, \\
\hline & & National, New & IFFCO Tokyo, & Oriental, \\
\hline \multirow[t]{2}{*}{ 2004-05 } & & India, Royal & United & Reliance \\
\hline & Cholamandalam, & IFFCO Tokyo, & ICICI Lombard, New & Bajaj Allianz, \\
\hline \multirow[t]{3}{*}{$2005-06$} & HDFC, Tata AIG & National, Royal & India, Oriental & Reliance, United \\
\hline & Cholamandalam, & Bajaj Allianz, & ICICI Lombard, & New India, \\
\hline & HDFC, Tata AIG & IFFCO Tokyo, & National, United & Oriental, \\
\hline \multirow[t]{3}{*}{$2006-07$} & & Royal & & Reliance \\
\hline & HDFC, Tata AIG & Cholamandalam, & Bajaj Allianz, IFFCO & ICICI Lombard, \\
\hline & & National, Reliance, & Tokyo, Oriental & New India, \\
\hline \multirow[t]{3}{*}{ 2007-08 } & & Royal & & United \\
\hline & HDFC, Royal, Tata & Bajaj Allianz, & ICICI Lombard, New & IFFCO Tokyo, \\
\hline & AIG & Cholamandalam, & India, United & National, \\
\hline \multirow[t]{3}{*}{ 2008-09 } & & Reliance & & Oriental \\
\hline & Cholamandalam, & New India, & Bajaj Allianz, IFFCO & HDFC, ICICI \\
\hline & Royal, Tata AIG & Oriental, Reliance & Tokyo, National & Lombard, \\
\hline $2009-10$ & & & & United \\
\hline
\end{tabular}




\begin{tabular}{|c|c|c|c|c|}
\hline Year & $<\mathrm{Q}_{1}$ & $\mathrm{Q}_{1} \mathrm{Q}_{2}$ & $\mathrm{Q}_{2} \mathrm{Q}_{3}$ & $>Q_{3}$ \\
\hline \multirow{5}{*}{$2010-11$} & Reliance, Royal, & Bajaj Allianz, & HDFC, New India, & ICICI Lombard, \\
\hline & Tata AIG & Cholamandalam, & United & National, \\
\hline & & IFFCO Tokyo & & Oriental \\
\hline & Reliance, Royal, & Bajaj Allianz, & HDFC, IFFCO & ICICI Lombard, \\
\hline & Tata AIG & Cholamandalam & Tokyo, National, & Oriental, United \\
\hline $2011-12$ & & & New India & \\
\hline
\end{tabular}

Source: Compiled by the authors

Furthermore, for a look into the specific results, the scores of the overall or technical efficiency the next table (No.3) is incorporated to highlight for the insurers.

Table 3

Efficiency Results of Private Insurers on the basis of Overall Efficiency

\begin{tabular}{cccccccccc}
\hline Insurer & $2004-$ & $2005-$ & $2006-$ & $2007-$ & $2008-$ & $2009-$ & $2010-$ & $2011-$ & Avg. \\
TE scores & 05 & 06 & 07 & 08 & 09 & 10 & 11 & 12 & \\
\hline Bajaj Allianz & 0.81 & 1.00 & 0.81 & 0.84 & 0.86 & 0.84 & 0.69 & 0.73 & 0.82 \\
Cholamandalam & 0.53 & 0.62 & 0.58 & 0.70 & 0.85 & 0.74 & 0.65 & 0.67 & 0.67 \\
HDFC Ergo & 0.43 & 0.48 & 0.42 & 0.57 & 0.61 & 1.00 & 0.84 & 0.93 & 0.66 \\
ICICI Lombard & 1.00 & 0.94 & 0.99 & 1.00 & 1.00 & 1.00 & 1.00 & 1.00 & 0.99 \\
IFFCO Tokyo & 0.82 & 0.91 & 0.75 & 0.89 & 1.00 & 0.89 & 0.77 & 0.85 & 0.86 \\
Reliance & 0.93 & 1.00 & 1.00 & 0.66 & 0.73 & 0.79 & 0.58 & 0.64 & 0.79 \\
Royal & & & & & & & & & \\
Sundaram & 0.54 & 0.65 & 0.60 & 0.67 & 0.71 & 0.71 & 0.61 & 0.66 & 0.64 \\
Tata AIG & 0.47 & 0.57 & 0.48 & 0.55 & 0.55 & 0.53 & 0.58 & 0.64 & 0.54 \\
Mean score & 0.69 & 0.77 & 0.70 & 0.73 & 0.79 & 0.81 & 0.72 & 0.76 & 0.69 \\
\hline
\end{tabular}

Source: Computed by the authors

The above results show the clear dominance of ICICI Lombard Insurance over its competitors. The average mean score is well below 1 in all years which demonstrates that there were wide variations among private insurers. It attained $100 \%$ relative efficiency in all but two years (in 2005-06 and 2006-07). It is followed by IFFCO Tokyo (86\%) and Bajaj Allianz General (82\%). Reliance General Insurance (79\%) is next placed with all the remaining players attaining an average score of less than $70 \%$ efficiency. Cholamandalam Insurance, HDFC General Insurance and Royal Sundaram Insurance show the technical efficiency average score lying in the range of $64 \%$ to $67 \%$; Tata AIG General Insurance is found to be the worst performer with the mean score of less than $60 \%$ (i.e., $54.50 \%$ ). The following table (No. 4) focuses on the performance of the public sector insurers in terms of their overall efficiency. 
Table 4

Efficiency Results of Private Insurers on the basis of Technical Efficiency

\begin{tabular}{cccccccccc}
\hline Insurer & $2004-$ & $2005-$ & $2006-$ & $2007-$ & $2008-$ & $2009-$ & $2010-$ & $2011-$ & Avg. \\
TE scores & 05 & 06 & 07 & 08 & 09 & 10 & 11 & 12 & \\
\hline National & 0.69 & 0.80 & 0.89 & 0.82 & 1.00 & 0.84 & 1.00 & 0.98 & 0.88 \\
New India & 0.78 & 0.96 & 1.00 & 1.00 & 0.93 & 0.82 & 0.86 & 0.85 & 0.90 \\
Oriental & 1.00 & 0.92 & 1.00 & 0.86 & 1.00 & 0.82 & 0.90 & 1.00 & 0.94 \\
United & 0.90 & 1.00 & 0.93 & 0.95 & 0.99 & 1.00 & 0.88 & 1.00 & 0.96 \\
Mean score & 0.84 & 0.92 & 0.96 & 0.91 & 0.98 & 0.87 & 0.91 & 0.96 & \\
\hline
\end{tabular}

Source: Computed by the authors

The above results show the performance of the public non-life insurers during the study period. On the basis of high mean score of technical efficiency that varies between 0.84 to 0.98 it appeared that efficiency among public insurers is more or less consistent. The industry average has consistently remained more than $90 \%$ in almost all the years of the study period. Moreover, the range is narrow with the lower and upper limits being $84 \%$ and $98 \%$. Though the score of all the players is very close, United Insurance (with efficiency of 94\%) stands marginally ahead of the other players and are very closely followed by Oriental Insurance and New India Assurance.

\section{Testing For Differences Between The Two Sectors}

In this section, the researchers have made an attempt to find out if there is any significant difference between the two sectors in terms of their performance. Before applying any statistical test blind-folded, the test for normality is done to find out the appropriate test. For the purpose, the Kolmogorov-Smirnov test was run on the technical scores obtained in different years.

Table 5

Tests for Normality of Data

\begin{tabular}{cccc}
\hline \multirow{2}{*}{ Year } & \multicolumn{3}{c}{ Kolmogorov-Smirnov Test } \\
\cline { 2 - 4 } & Statistic & Df & Sig. \\
\hline $2004-05$ & .169 & 12 & .200 \\
$2005-06$ & .262 & 12 & .023 \\
$2006-07$ & .184 & 12 & .200 \\
$2007-08$ & .143 & 12 & .200 \\
$2008-09$ & .215 & 12 & .132 \\
\hline
\end{tabular}

(Continued) 


\begin{tabular}{cccc}
\hline \multirow{2}{*}{ Year } & \multicolumn{3}{c}{ Kolmogorov-Smirnov Test } \\
\cline { 2 - 4 } & Statistic & Df & Sig. \\
\hline $2009-10$ & .142 & 12 & .200 \\
$2010-11$ & .147 & 12 & .200 \\
$2011-12$ & .188 & 12 & .200 \\
\hline
\end{tabular}

a. Lilliefors Significance Correction

Source. Computed by the authors

From the above results, it is evident from the outcome of the Kolmogorov-Smirnov test that the data is normal for the years 2004-05, 2006-07, 2007-08, 2008-09, 2009-10, 2010-11 and 2011-12. Hence, in order to find out the statistical difference in the efficiency score of the two sectors, an appropriate test is applied.

In the years where normality is found, the ' $t$ ' test is applied; in the remaining years the MannWhitney $\mathrm{U}$ test is applied.

The summary of the results is given in the table 6 .

Table 6

Results for Test of Difference

\begin{tabular}{c|c}
\hline Year & Significant difference, if any? \\
\hline $2004-05$ & No \\
\hline $2005-06$ & No \\
\hline $2006-07$ & Yes \\
\hline $2007-08$ & Yes $^{* * *}$ \\
\hline $2008-09$ & Yes $^{* * *}$ \\
\hline $2009-10$ & No \\
\hline $2010-11$ & Yes \\
\hline $2011-12$ & Yes \\
\hline
\end{tabular}

Source. Computed by the authors

$*$ At $1 \%$ level, $* *$ at $5 \%$ level, $* * *$ at $10 \%$ level.

From the above results, it is observed that in the initial years, there is no significant difference between the two sectors. However, in almost all the other years, there is a significant difference in terms of overall efficiency between the two sectors. Out of the five years, a significant difference is noticed, in four years, the difference is significant at $5 \%$ level.

\section{Concluding Remarks}

The present study points to the overall high efficiency in the general insurance industry in the country. The percentage of inefficiency in all the three categories is quite low. Both public and private players have performed well in the industry. The empirical analysis reveals that of 
the private sector, Reliance General and ICICI Lombard have consistently performed well On the other hand, of the public sector counterpart; United India Assurance and Oriental Insurance have outperformed the other two in terms of overall trend in the study period.

It is, therefore, inferred that de-tariffing in the sector which lead to an open-market scenario (instead of an administered pricing policy) did not have any noticeable impact on the overall efficiency picture in the sector. It is clear from the analysis that both the sectors have prepared themselves well by launching their products at a competitive price in terms of the premium charged against the costs borne. It is, therefore, evident that the industry, as a whole, took up the challenging environmental change with a strong strategic adaptation. As there has not been any drastic negative impact on the insurers, there is a high chance that it is likely to transform the insurance market further that will help it to reach global standards. The only need of the hour is to create the right 'positioning' in the minds of the customers that will help the insurers to penetrate the market further and grab a greater market share. However, with regard to the differences between the two sectors, there is no consistency in the results; in the later years, a significant difference between the public and private players is observed. Notwithstanding the fact that the sector as a whole has adopted itself to the challenge quite fast, still there is sufficient scope for the industry, keeping in mind the low insurance penetration and the density levels that are existing in the country.

\section{References}

Abidin, Z., \& Cabanda, E. (2011). Efficiency of non-life Insurance in Indonesia. Journal of Economics, Business and Accountancy Ventura, 14(3),197-202.

Bawa, S. K., \& Ruchita, M. (2011). Efficiencies of health insurance business in India: An application of DEA. American Journal of Social and Management Sciences, 2(2), 237-247.
Chakraborty, K., Dutta, A. \& Sengupta, P. P. (2012). Analyzing firm performance in non-life insurance industry-Parametric and non-parametric approaches. Indian Journal of Economics and Business, 11(1), 1-23.

Coelli, T. J., (2004). Efficiency and productivity measurement: An overview of concepts, terminology and methods. Paper presented at the short course on "Productivity and Efficiency Measurement Methods with applications to infrastructure industries", University of Queensland, Australia, 25-27.

Cummins, J. D., Tennyson, S., \& Weiss, M. A. (1999). Consolidation and efficiency in the US life insurance industry. Journal of Banking and Finance, 23, 325-357.

Delhausse, B., Fecher, F., Perelman, S., \& Pestieau, P. (1995). Measuring productive performance in the non-life insurance industry: The case of French and Belgian markets. Tijdschrift Voor Economic En Management, XL(1), 4769.

Diacon, S., Starkey, K., \& O'Brien, C. (2002). Size and efficiency in European longterm insurance companies. Centre for Risk and Insurance Studies, The University of Nottingham, Discussion Paper Series, VII, 1-35.

Eckles, D. L., \& Saardchom, N. (2007). Technical and scale efficiency in the Thai non-life insurance industry. NIDA Business Journal, 3, 105-124.

Hao, J. C. J., \& Chou, L. (2005). The estimation of efficiency for life insurance industry: The case in Taiwan. Journal of Asian Economics, 16, 847-860.

Hsiao, S., (2006). A study of investment performance and overall financial performance for life insurers in Taiwan. Accessed at www. centerforpbbefr.rutgers.edu/2006/ Paper\%202006/ 03AS-077-ShuHua\%Hsiao.pdf in August 2012

Hsiao, S., Pai, T., Shih, M. \& Su, S. (2011). Cost efficiency in the life insurance industry. Journal of Convergence 
Information Technology, 6(3), 120131.

Hwang, S. N. \& Kao, T. L (2006). Measuring managerial efficiency in non-life insurance companies: An application of two stage Data Envelopment Analysis. International Journal of Management, 23(3), 699-720.

Ibiwoye, A., (2010). Evaluating financial services productivity: A comparison of ratios, index numbers and frontier methods. Journal of Economics and Engineering, 50-58.

Lee, H., \& Kim, K. (2008). Decomposition and super-efficiency in the Korean life insurance industry employing DEA. International Journal of Contents, 4(3), 1-8.

Lin, L. F., (2002). Deregulation and efficiency in the Taiwan life insurance industry. Temple University. PhD dissertation.

Owusu-Ansah, E., Dontwi, I.K., Seidu, B., Abudulai, G. \& Sebil, C. (2010). Technical efficiencies of Ghanaian general insurers. American Journal of Social and Management Sciences, 1(1), 75-87.
Qiu, S., \& Chen, B. (2006). Efficiencies of life insurers in China: An application of Data Envelopment Analysis. Review of Economics and Statistics, 74(2), 221-230.

Rao, G. S. S. B., \& Venkateshwarlu, R. (2014). Efficiency of Indian private non-life insurance firms using stochastic frontier analysis. IOSR Journal of Economics and Finance, 4(1), 42-46.

Saeidy, P., \& Kazemipour, S. A. (2011). Compare the performance of private and public insurance companies in using Data Envelopment Analysis. World Applied Sciences Journal, 13(5), 988-992.

Sinha, A. (2013). A study on performance of public and private life insurance companies in India. Ph.D Thesis, University of Kalyani 